\title{
In vitro release studies on drugs suspended in non-polar media ${ }^{1}$
}

\author{
The release of sodium chloride, paracetamol and chloramphenicol from suspensions in \\ liquid paraffin
}

DR. D. J. A. CROMMELIN ${ }^{2}$

\section{INTRODUCTION}

Although suppositories have been used in rectal therapy for years, only recently the biopharmaceutical properties of this type of dosage form have been studied more extensively, showing that its biopharmaceutical behaviour strongly depends on the physicochemical properties of the vehicle and the drug concerned. In the present study an attempt was made to gain insight into the mechanisms involved in the release of drugs suspended in fatty suppository bases. Only if these mechanisms are known rational predictions can be made about the required composition of a suspension suppository with respect to its release characteristics.

When fatty suspension suppositories are administered the release process for each particle can be considered to proceed according to the following scheme (Fig. I):

a. melting of the suppository;

b. spreading of the suppository over the rectal mucosa;

c. transport of the suspended drug particles to the interface between the oil layer and the rectal fluid;

d. passage of the particles through this interface and

e. dissolution in the rectal fluid.

Only the last three steps, i.e. transport, passage and dissolution were taken into account.

In the model system used (Fig. 2) the release of different solids suspended in liquid paraffin was studied, keeping the interfacial area constant. A limited number of variables which were expected to influence the release was selected:

I. solubility of the solid in water: sodium chloride $360 \mathrm{mg} / \mathrm{ml}$, paracetamol $13 \mathrm{mg} / \mathrm{ml}$ and chloramphenicol $3.6 \mathrm{mg} / \mathrm{ml}$;

2. particle size: classified fractions between 5 and $60 \mu \mathrm{m}$;

3. concentration of the solid in the apolar liquid: up to $10 \% \mathrm{~m} / \mathrm{m}$;

4. presence of additives in the apolar liquid: di-(2-ethyl-hexyl) sodium sulphosuccinate (Doss-Na), sorbitan trioleate (Span 85) and water. Both Doss- $\mathrm{Na}$ and Span 85 dissolve in liquid paraffin in the concentrations used. Water dissolves up to about $0.01 \% \mathrm{~m} / \mathrm{m}$.

\section{RESULTS}

Wetting and dissolution of sodium chloride particles did not take considerable time. So, transport to the interface - which means essentially sedimentation in the model system used - was the rate-limiting step. This indicated that the primary particle size or the size of possibly formed agglomerates is of utmost importance. Calculations based on analysis of the repulsive and attractive forces involved, showed that in undisturbed liquid paraffin particles of around $10 \mu \mathrm{m}$ tend to adhere upon collision, forming agglomerates which settle faster than the primary particles themselves. These agglomerates are expected to break up if low shear rates are applied, as those occurring during shaking or rotating the suspension by hand. From theory it was also derived that trace amounts of water $(0.05 \% \mathrm{~m} / \mathrm{m})$ in paraf-

\footnotetext{
'Autoreferaat van het gelijknamige proefschrift, Leiden 26 juni 1979. Promotor: Prof. Dr. c. J. DE BLAEY, co-promotor: Prof. J. Polderman; co-referenten Dr. N. A. ARMSTrong, Prof. Dr. Ir. C. F. Lerk en Dr. P. H. WIERSEMA.

${ }^{2}$ Afdeling Farmaceutische technologie en Biofarmacie, Subfaculteit Farmacie, Rijksuniversiteit Leiden; thans afdeling Praktische Farmacie, Subfaculteit Farmacie, Rijksuniversiteit Utrecht. Tijdelijk adres (tot I augustus I980) College of Pharmacy, Department of Pharmaceutical Chemistry, University of Michigan, Ann Arbor, Michigan 48ro4, UsA.
} 
a. Melting

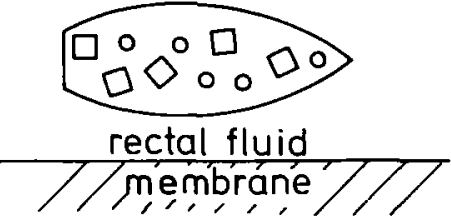

b. Spreading

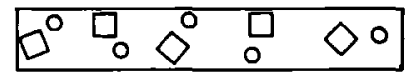

c. Transport

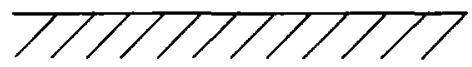

d. Passage

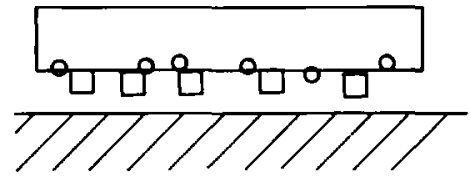

e. Dissolution

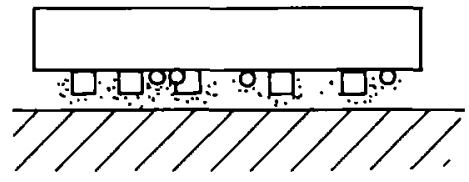

Fig. I. Processes involved in the release of drugs from fatty suspension suppositories

fin tend to stabilise agglomerates strongly by the formation of liquid bridges between two particles. Particles held together by these liquid bridges can only be separated if very high shear rates are applied (order of magnitude $50000 \mathrm{~s}^{-1}$ ). Addition of surfactants can prevent agglomeration by changing electrostatic repulsion and van der waals attractive forces or by steric stabilisation. The ultimate effects of surfactants on the degree of agglomeration is still difficult to predict.

The importance of the parameters mentioned above is illustrated by the following examples. In Figure 3 the effect of concentration of sodium chloride on the release rate is shown. The release rate of suspensions with the same particle size fraction strongly increased with the concentration, due to an increasing rate of collision of the primary particles leading

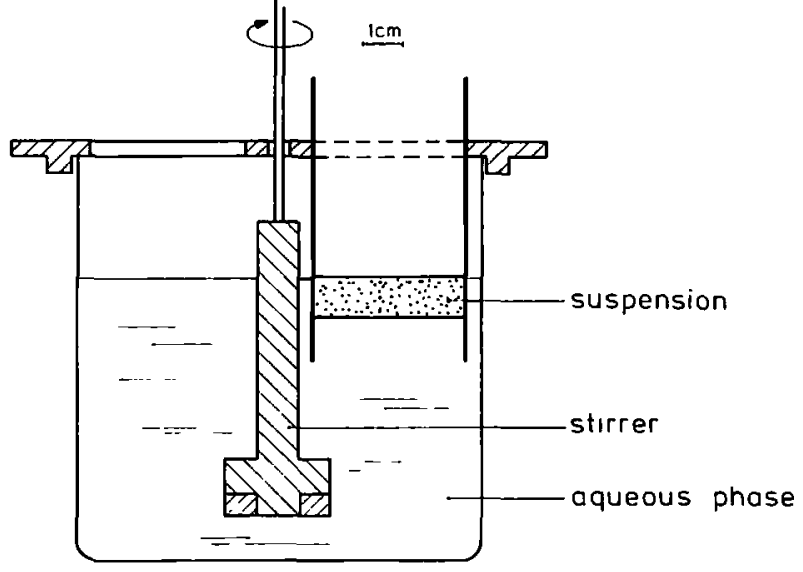

Fig. 2. Apparatus used for the determination of the release rate

to the formation of larger agglomerates. These findings were consistent with theoretical predictions. The formation and size of agglomerates, and consequently the release rate, was reduced by the addition of Doss-Na as is shown in Figure 4 (for a $5 \% \mathrm{~m} / \mathrm{m}$ sodium chloride suspension with different concentrations of Doss-Na).

For substances like paracetamol and chloramphenicol, which are less water soluble, the release can either be controlled by sedimentation - like sodium chloride - or by dissolution, since wetting proved to be rapid. In the case of dissolution - limited transport the particles

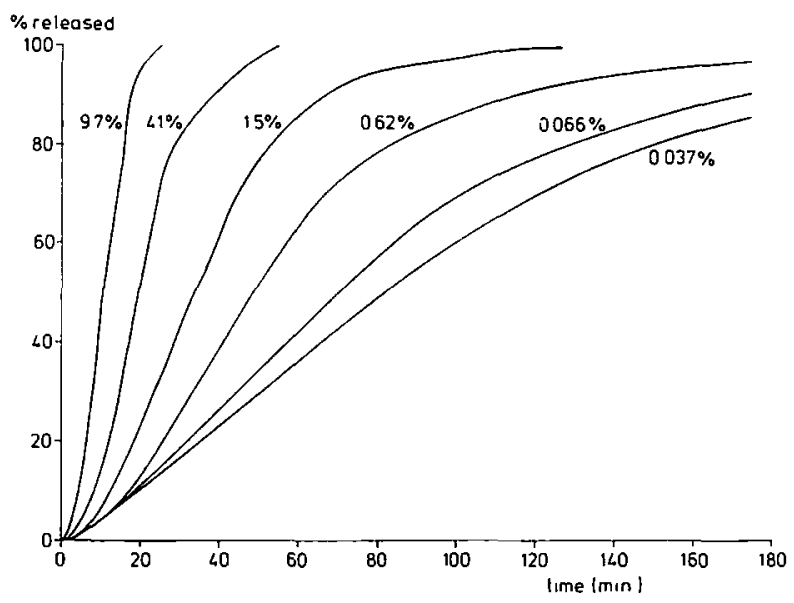

Fig. 3. Influence of the concentration of sodium chloride suspended in liquid paraffin on the release; mean particle size $10 \mu \mathrm{m}$; concentration of sodium chloride in liquid paraffin is expressed in $\% \mathrm{~m} / \mathrm{m}$ 
orientate themselves as is schematically shown in Figure 5.

The position of the particles at the liquid paraffin/water interface depends on the interfacial tension, the contact angle in the solid/ liquid paraffin/water system and the mass and the form of the particles. For chloramphenicol and paracetamol contact angles of about $90^{\circ}$ were measured at the water/liquid paraffin interface. Even in the case of a very thick, fluffy sediment on the interface, which means that only a small fraction of the particles is in contact with the water layer, it could be demonstrated by analysis of the forces acting at the interface that the sediment will stay on the interface during dissolution. It could also be deduced that the degree of coverage of the interface would have no influence on the dissolution rate as long as particle dimensions and interparticle distances at the interface are small compared to the effective stagnant layer. The effective stagnant layer in the aqueous phase of the set-up used (Fig. 2) was about 200 $\mu \mathrm{m}$. Consequently, with a sediment on the interface the release rate would be controlled by the dimensions of the interface and become independent of particle size and concentration.

As shown in Figure 6 the initial release rate indeed increased with concentration for the two particle size fractions of chloramphenicol studied, indicating sedimentation rate control. However, above certain concentrations this increase in rate leveled off and the initial release rate became dissolution controlled. Then this rate was found to be hardly dependent on

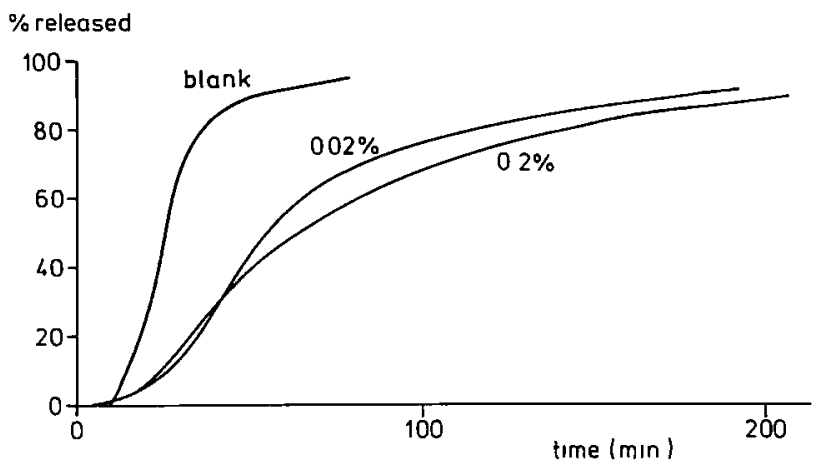

Fig. 4. Influence of the concentration $(\% \mathrm{~m} / \mathrm{m})$ of Doss- $\mathrm{Na}$ dissolved in liquid paraffin on the release of sodium chloride $(5 \% \mathrm{~m} / \mathrm{m})$; mean particle size sodium chloride $8 \mu \mathrm{m}$

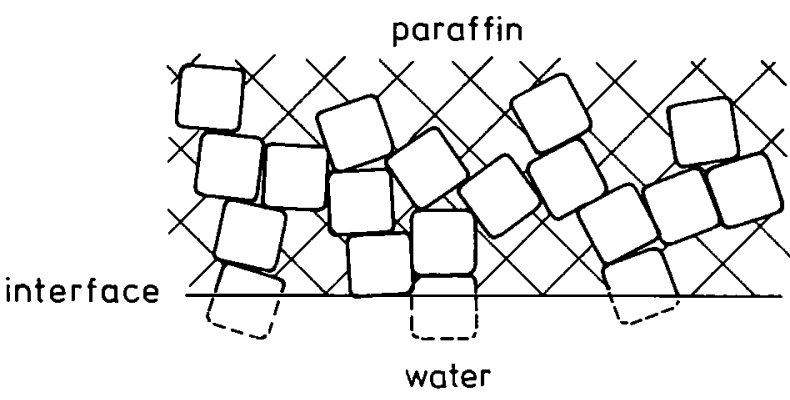

Fig. 5. Situation at the interface when dissolution determines the release rate. Contact angle (measured through the aqueous phase): $0<\Theta<90^{\circ}$

particle size and degree of coverage, in the range studied (between 7.5 and $100 \%$ ); the $100 \%$ value was established by positioning tablets at the interface. Under dissolution controlled conditions additives influenced the initial release rate differently. Doss- $\mathrm{Na}$ tended to decrease the supporting capacity of the interface by both decreasing the interfacial tension and also improving the wetting of the solid by water. Low concentrations of water in the liquid paraffin strengthened this trend. When the particles fell through the interface into the aqueous phase instead of staying on it, the effective surface area dramatically increased, thus increasing the dissolution rate. On the other hand Span 85 tended to reduce the wetting of the particles by the aqueous phase. It

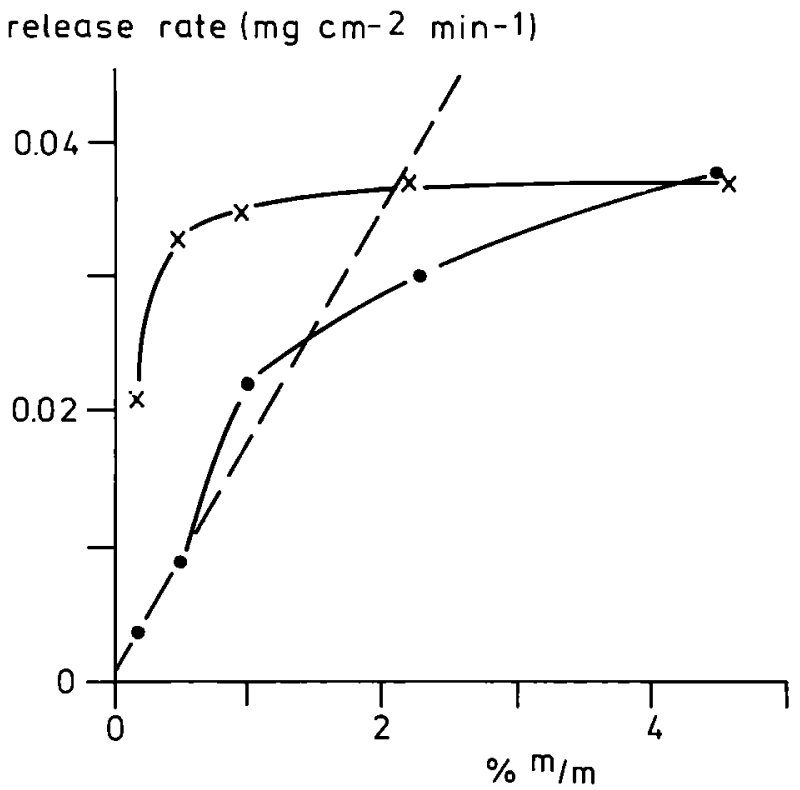

Fig. 6. The initial release rate as a function of the concentration of chloramphenicol; $5 \mu \mathrm{m}$ fraction, $\times 27 \mu \mathrm{m}$ fraction 
prevented sodium chloride, paracetamol and chloramphenicol particles from contacting the aqueous layer, blocking the release completely.

\section{CONCLUSION}

Physicochemical theories on the stability of particles against agglomeration, the behaviour of particles at the interface and dissolution appeared to act as powerful tools in predicting the rate controlling steps in the model system used. For such a prediction only basic physicochemical properties of the system involved, which are available in the literature or can easily be measured, have to be known. In the present study not only the primary particle size, but also the agglomeration behaviour and therefore the concentration were important factors, particularly when transport to the interface was the rate-limiting step. But, the initial release rate became independent of particle size and concentration when dissolution at the interface limited the rate. Additives present in low con- centrations had a decisive influence on the behaviour of the particles in the suspension and at the interface, and thus on the dissolution rate.

The relevance of this model study for the design and development of rectal dosage forms is that an insight has been gained into the basic mechanisms involved in the release of solid substances from an apolar medium. Extrapolation of the results to the in vivo release is speculative, because as stated in the introduction, the in vivo release process was studied only in part and under conditions in many ways different from the in vivo situation. Investigations are in progress to study the spreading of suppositories in vivo and to establish the exact conditions in the rectum after administration of a suppository in order to be able to improve the in vitro simulation of the in vivo situation.

Ontvangen bij de redactie februari 1980 . Aangenomen voor plaatsing 1980 .

\section{REFERATEN}

\section{Langdurige subcutane insuline- infusie bij diabetici}

\section{(Overzichtsreferaat)}

De huidige behandeling van diabetes mellitus met insuline is geenszins een nabootsing van de natuurlijke gang van zaken. Een goede aanpassing van de insulinespiegel aan de wisselende behoefte vindt niet plaats. Mogelijk kan door een verbeterde beheersing van de diabetes de ontwikkeling van micro-angiopathie (degeneratieve veranderingen van de kleine bloedvaten bij diabetici, o.a. retinopathie) worden verminderd of voorkomen.

Door de groep van PICKUP (1978; 1979a, b) is een methode ontwikkeld, waarbij middels een subcutaan insuline-infuus (sc.i.i.) een dergelijke verbeterde controle wordt nagestreefd. De insuline wordt toegediend met behulp van een kleine infuuspomp ( $144 \times 72 \times 23 \mathrm{~mm}$, gewicht $300 \mathrm{~g}$ ) die met een riem om het middel van de patiënt wordt bevestigd. Door indruk- ken van een knop (dit moet een half uur vóór een maaltijd geschieden) kan de patiënt de basale infusiesnelheid van het apparaat ( $50 \mu \mathrm{l}$ / uur) voor een geautomatiseerde tijdsduur van zeventien minuten overschakelen op een hogere snelheid (400 $\mu \mathrm{l} / \mathrm{uur})$. De insulineconcentratie in de injectiespuit is aangepast aan de behoefte van de patiënt door geschikte verdunning van de insuline met fysiologische zoutoplossing. De insuline wordt aan de patiënt toegediend middels een canule, die in het subcutane weefsel van de vóórbuikwand is gefixeerd.

In de eerste publikatie (PICKUP e.a. I978) worden de resultaten van deze methode beschreven bij twaalf diabetici door de 24-uurs bloedsuikercurve tijdens sc.i.i. en tijdens de gebruikelijke depotinjectie onder gestandaardiseerde omstandigheden te vergelijken. In vijf van de veertien gevallen bleek de gemiddelde bloedglucoseconcentratie tijdens sc.i.i. te zijn verlaagd zonder dat daarbij hypoglykemieën optraden; in zes gevallen was de gemiddelde bloedglucoseconcentratie onveranderd. De spreiding in de concentratie verminderde bij 